\title{
Research on Dispersive Discrimination Test Methods of Illite Clay Soils in Zhejiang
}

\author{
Shihua CHEN \\ Zhejiang Provincial Key Laboratory of Hydraulic Disaster \\ Prevention and Mitigation \\ Zhejiang Institute of Hydraulics \& Estuary \\ Hangzhou, China \\ E-mail: chensh@zjwater.gov.cn
}

\author{
Yaohui HE \\ Zhejiang Provincial Key Laboratory of Hydraulic Disaster \\ Prevention and Mitigation \\ Zhejiang Institute of Hydraulics \& Estuary \\ Hangzhou, China \\ E-mail: 56668442@qq.com
}

\author{
Shuijin SHEN \\ Zhejiang Provincial Key Laboratory of Hydraulic Disaster \\ Prevention and Mitigation \\ Zhejiang Institute of Hydraulics \& Estuary \\ Hangzhou, China \\ E-mail: 40422615@qq.com \\ Qinghong MA \\ Zhejiang Provincial Key Laboratory of Hydraulic Disaster \\ Prevention and Mitigation \\ Zhejiang Institute of Hydraulics \& Estuary \\ Hangzhou, China \\ E-mail: m_qinghong@126.com
}

\begin{abstract}
Numerous studies indicate that dispersive clay minerals are mostly composed of montmorillonite, while the major mineral composition of dispersive clay is illite in Zhejiang Province. Based on the particularity of dispersive clay soil in this region, A series of experimental study and comparison and analysis work have been done to make test methods and discrimination results of the crumb test, the pinhole test, the double-hydrometer test and the pore water soluble salt test are more closed with engineering practice. The test methods were improved, and the discrimination standard of the double-hydrometer test was modified. For different test methods have different mechanisms, the dispersion of soil cannot be comprehensively distinguished by single one test, so, the synthetic discrimination method was proposed to judge the dispersion of clay accurately. The experimental results provide a theoretical basis and technical guidance for soil choice in related engineering projects.
\end{abstract}

Keywords-geotechnical engineering; dispersive clay soil; test research; Zhejiang; illite

\section{INTRODUCTION}

The dispersive clay is a clay that in low salinity water, the cohesion between the fine particles are most or all disappeared, and along with particles self-disperse into the primary-clay particles [1]. Despite some related studies show that the dispersion of clay almost have no influence on permeability[2], but due to its low anti-erosion ability, the stronger the dispersion, the smaller the permeation damage slope, so, it likely to cause piping leakage of dam, subgrade instability, etc. Therefore, it is very harmful to engineering. In recent years, it is one of the special soil types that attracts much attention in rock engineering field. Dispersive clay has been found in Australia, North America, India, Western Europe, and it also has been found in Heilongjiang, Shandong, Guangxi, Xinjiang and other provinces [3]. Since the dispersive clay has been discovered and recognized in 1950, many experts have done a lot of researches on it and achieved many valuable results. To discrimination method of dispersive clay, the famous American engineer Charade (J.L.Sherard), etc [4], took ubiquitous phenomenon of the dam dispersive clay erosion and lioxiviation destructions in United States into study since 1970. They put forward four test methods to identify dispersive clay, namely: crumb test, pinhole test, double-hydrometer test and pore water soluble salt cation test. Bell [5] researched the dispersive clay tests and believed that these test results were not entirely reliable, they cannot match well with each other. American Society for Testing and Materials (ASTM) has successively made three kinds of testing rules to discriminate clay dispersion, they are double-hydrometer test, pinhole test and crumb test.

Since the research of dispersive clay started late in China, so, there is no relevant code and specification to guide test procedures, mainly use foreign research methods. Nevertheless, some new concepts are proposed by our researchers through studying on dispersive clay. Yuezhang Qin[9] proposed to discriminate the soil dispersion by the mole rate of $\mathrm{Na}$ pinhole test. Henghui Fan[10] adopted the double-hydrometer test, pinhole test, crumb test, pore water soluble salt cation test and percentage of exchangeable sodium ion test five kinds of test methods to discriminate soil dispersion, but the results are not exactly consistent, there are some differences between each other; so, he based on his practical experience, according to the characteristics of the various tests, giving various test weighted value, which provided us with a more reasonable and reliable synthetic discrimination method to discriminate soil dispersion[11]. Zhanliang Tian[12] analyzed and summarized the research achievements recent years through the dispersion mechanism of dispersive clay, the discrimination methods of dispersive clay and engineering prevention and control of dispersive clay.

But up to now, many researchers point out that mineral composition of dispersive clay is most montmorillonite, while mineral composition of dispersive clay in Zhejiang area is illite, existing specifications or US ASTM D4221-99 standard is not applicable by considering the particularity of 
this region dispersive clay. In this paper, the research aimed at the fill of reservoir dam, a lot of work has been done, and has improved test methods of the crumb test, the pinhole test, the Double-hydrometer test and the pore water soluble salt cation test, adjusted double-hydrometer test discrimination standard. Finally, according to the test results of the above four methods, it provides a synthetic discrimination method to discriminate this kind clay dispersion.

\section{The Basic Physical Properties of the SoIL}

Test soil samples selected the fill of reservoir dam, the soil physical and mechanical properties are shown in Tab. 1. From Tab. 1, the specific gravity of Group 26 of the soil was $2.68 \sim 2.74$. particle composition of clay $(<0.005 \mathrm{~mm})$ content reached $30.0 \% \sim 48.6 \%$, the majority of that about $35 \%$.From the water ratio limit, the liquid limit water ratio is $24.5 \% \sim 37.2 \%$ and plastic limit water rate is $12.5 \% \sim 20.8 \%$, plasticity index is $10.0 \sim 16.7$, it discriminated as a sandcontained low liquid limit clay.

\section{Mineral COMPOSITION OF THE SOIL}

In order to study the mineral composition of the 26 soil samples. The samples have been taken the X-ray mineral phase quantitative analysis, and the results are shown in Tab. 2. As it can be seen from Tab. 2, the 26 soil samples are all free of montmorillonite, illite content reached $6.5 \% \sim 27.6 \%$, kaolin content reached $0 \sim 9.5 \%$, other minerals content reached $71.2 \%$ $93.5 \%$. Therefore, from the analysis of mineral composition, soil dispersion should be caused by illite. Content distributions of illite (see Fig. 1).

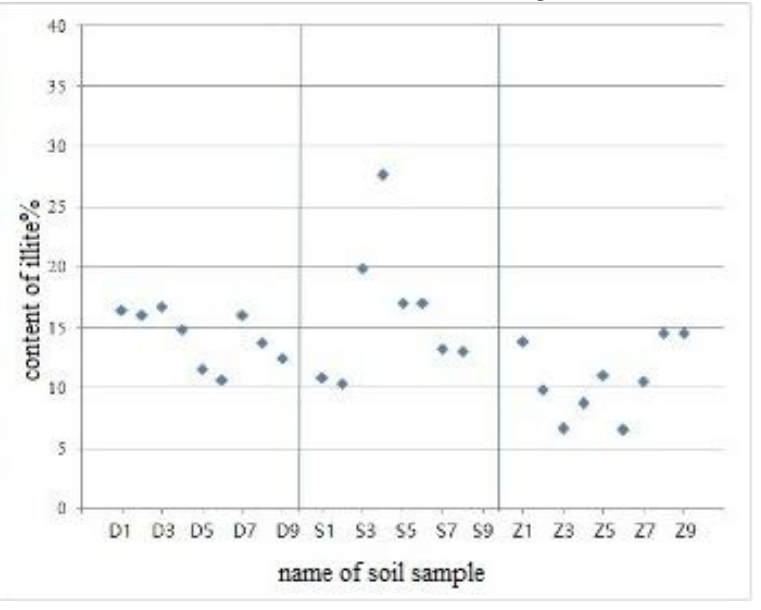

Figure 1. Content distributions of illite

\section{Dispersion Discrimination Test Method[6-8,13]}

The properties of dispersive clay are related to its physical and chemical state and electrochemical properties of the soil particle surface, while, test methods that commonly used for geotechnical engineering cannot reflect the chemical state of the soil and the soil particle surface electrochemical properties, so, the methods cannot be used to discriminate clay dispersion. At present, there are no relevant test regulations in China, we still use tests that American Society for Testing Materials are proposed: double-hydrometer test, pinhole test, pore water soluble salt test these four test methods to discriminate soil sample .For the common case illite clay in Zhejiang, in order to make test results of these four methods more close to the reality, and make the results match well, this paper has done some improvements about the four test methods and discrimination standard.

\section{A. Crumb Test}

Crumb test base on colloidal chemistry point of view that dispersive soil in water is due to the precipitation of colloidal particles, therefore, it take different degrees of colloidal precipitated as the discrimination standard. The test soil samples are made into a side length about $7 \mathrm{~mm} \sim 15 \mathrm{~mm}$ square soil clod ,then put them into the water, recording time, according to the clods particles dispersed in water properties and water turbidity to divided the dispersion grade of the soil samples into non-dispersion, transitional, dispersion and high dispersion four levels.

\section{B. Double-hydrometer Test}

Double-hydrometer test holds that the clay soil often shows granular structure, it is not easily broken down into individual particle in water, but for dispersive clay particles is very easy to disperse and flow away in water. Thus, soil samples need to take twice hydrometer tests to determine the clay $(<0.005 \mathrm{~mm})$ content, then obtaine the ratio --dispersion. The first time is the conventional method of adding the dispersant, the second time is non-conventional method without dispersant.

Dispersity calculations in double-hydrometer:

$$
\text { Dispersity }=\frac{\text { clay content }(<0.005 \mathrm{~mm}) \text { in conventional test }}{\text { clay content }(<0.005 \mathrm{~mm}) \text { in non-conventional test }} \times 100 \%
$$

Previous studies on dispersity discrimination standards are as follows: non-dispersion soil, the dispersity $<30 \%$; transitional soil, dispersity reach30\% 50\%; dispersive soil, the dispersity $>50 \%$. This paper based on the particularity of illite clay soil in Zhejiang area proposed the doublehydrometer method discrimination standard: non-dispersion soil, the dispersity $<60 \%$; transitional soil, dispersity reach $60 \% \sim 80 \%$; dispersion soil, dispersity $>80 \%$.

\section{Pinhole Test}

Pinhole test simulates that under a certain water head, soil pore walls of the particles have the ability to bear some of the kinetic energy of the water flow and erosion resistance, which represents the force required by separating particles. Pinhole test apparatus adopt equipment in Zhejiang Research Institute of Water Estuary self-made (see Fig. 2), the undisturbed soil sample or compacted to the required density of the dry soil sample was putted through a diameter at its axial center of the pore $1.0 \mathrm{~mm}$ and then used distilled water (or test required water) to conduct seepage test. Then observed the pinhole situation of fluvial abrasion at all levels of water head, then, determined the dispersity properties of soil according to the pinhole and changes in water flow and water color. Its discrimination standard: (1)dispersive clay: 
under $50 \mathrm{~mm}$ head, $10 \mathrm{~min}$ end, flow rate up to $0.8 \sim 1.8 \mathrm{ml} / \mathrm{s}$, water moderate turbidity $\sim$ turbidity, final pinhole aperture is not less than $1.5 \mathrm{~mm}$. (2) Transitional clay: under $180 \mathrm{~mm}$ head, $5 \mathrm{~min}$ end, flow rate up to $1.2 \sim 2.8 \mathrm{ml} / \mathrm{s}$, water become turbid., pinholes final aperture is not less than $1.5 \mathrm{~mm}$; or under $380 \mathrm{~mm}$ head, $5 \mathrm{~min}$ end, flow rate of $1.8 \mathrm{ml} / \mathrm{s}$ above, water gradual turbid. (3non-dispersion clay: under $380 \mathrm{~mm}$ head, $5 \mathrm{~min}$ end, flow rate does not exceed $1.8 \mathrm{ml} / \mathrm{s}$, water is clear, final pinhole aperture is substantially unchanged.

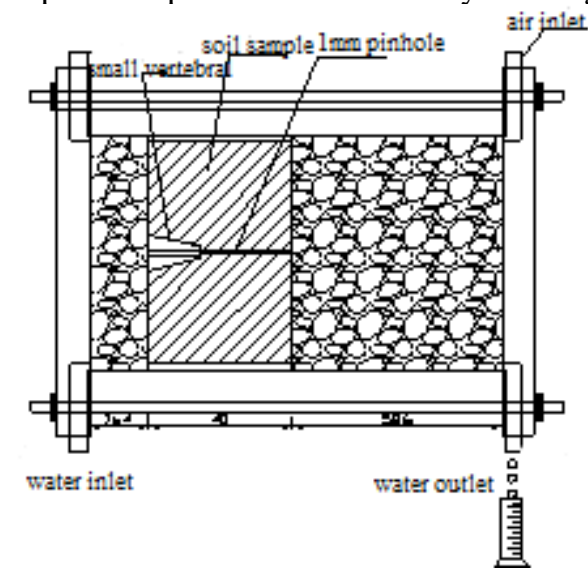

Figure 2. Schematic diagram of pinhole test device(The unit in the figure is $\mathrm{mm}$ )

\section{Pore Water Soluble Salt Test}

Pore water soluble salts test from chemical point of view holds that the relative amount of dissolved sodium ions of pore water in dispersive clay and other alkali cation (calcium and magnesium) is the major factor to determine the clay dispersion. Mixing soil and distilled water closely to the liquid limit of consistency, using a filter with a vacuum suction device or centrifuge to separate the pore water sample, determining the calcium, magnesium, sodium, potassium these four kinds of metal cation in the pore water samples, the total amount called as TDS. PS (Sodium percentage) refers as the sodium cation proportion. Then we can get the relationship between soil dispersion and TDS curve in Fig. 3.

$$
\mathrm{TDS}=\mathrm{Na}^{+}+\mathrm{K}^{+}+\mathrm{Ca}^{2+}+\mathrm{Mg}^{2+}
$$

$$
\mathrm{PS}=\mathrm{Na}^{+} / \mathrm{TDS}
$$

$$
\mathrm{SAR}=\mathrm{Na}^{+} / \sqrt{\left(\mathrm{Ca}^{2+}+\mathrm{Mg}^{2+}\right) / 2}
$$

Pore water soluble salt test quantitative analysis the soil sample dispersion by the sodium ion and other alkali cation (calcium and magnesium) relative amount dissolved in the pore water; it is also a relatively reliable method. It extracted saturated soil pore water by equipment that developed by Zhejiang Research Institute of Water Estuary (see Figure 4), when extract the pore water, firstly put into a same-size paper in the funnel, then load the vicinity of the liquid limit soil sample in the funnel, and make sure the soil is closely contact with the funnel around, assemble equipment as Fig.4, soil pore water drop from soil to suction flask graduated cylinder under the external atmospheric pressure then get clear pore water.

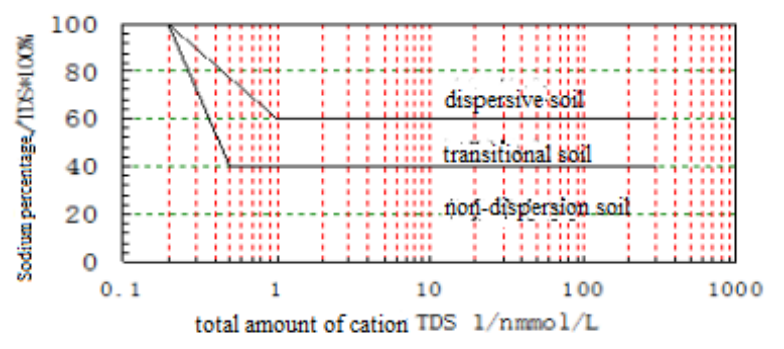

Figure 3. Relationship curve of soil dispersion with TDS

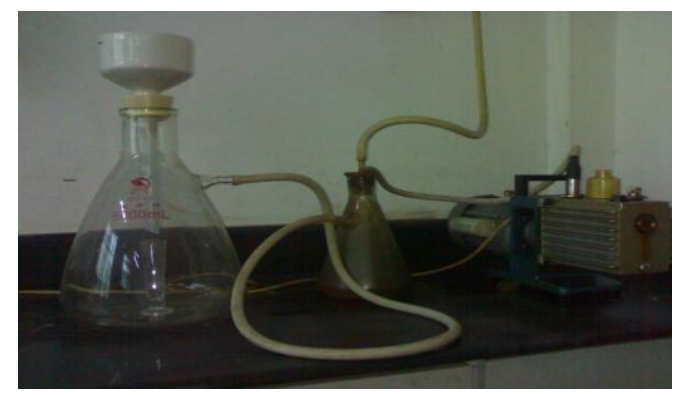

Figure 4. Extraction device of saturated soil pore water

\section{E. Synthetic Discrimination Method and Steps}

Due to the different mechanisms of these four test methods for discriminating dispersive clay, single one test method cannot comprehensively determine the dispersion of soil. Therefore, we should adopt a synthetic discrimination method to determine its dispersion. Taking account of the four methods, the crumb test and the pinhole test are closest to actual state of engineering, they can more directly and effectively reflect the dispersion of the soil. They should be considered firstly. In addition, the author has modified double-hydrometer test discrimination standard through a large number of experimental studies and analysis and comparison work. So that the determination result that use the modified double-hydrometer test discrimination standard can be adopted as the primary basis for discrimination. For these reasons, we recommend that this clay dispersion of synthetic discrimination step as follows:

Step one: crumb test, pinhole test and double-hydrometer test, if there are 2 (or 3 ) of the test results consistent with the discrimination result, the soil sample can be determined its level for the dispersion.

Step two: If the above 3 kinds of results were all inconsistent with each other, Then, when pore water soluble salts the test result is consistent with one outcome above 
three tests results, the soil sample can be determined its level for the dispersion.

Synthetic discrimination flowchart see Fig. 5.

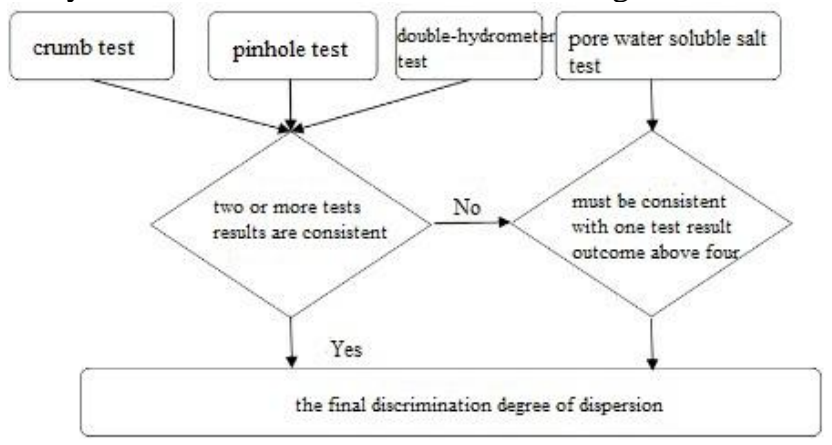

Figure 5. Flowchart of dispersive clay

\section{AnAlysis OF TeSt Results}

\section{A. Test Results}

26 soil samples were separately carried on crumb test, double-hydrometer test, pinhole test and pore water soluble salt test, which four tests different dispersion and synthetic discrimination results in Tab. 3 .

\section{B. Analysis of Test Results}

Through the results for 26 groups of clay samples from the reservoir dam were tested by methods described above, the discrimination results obtained from above four methods and synthetic discrimination method comparing apparent showed as follow (Tab. 3):

(1) The results of crumb test that is determined as dispersed or transition, which is consistent with the synthetic discrimination results; there are just four groups of soil samples results compared to the synthetic discrimination results showed inconsistent.

(2) Pinhole test results compared with the discrimination results, there are 14 groups of soil samples are the same, and another seven groups of soil sample results are determined as transition but synthetic discrimination determined as dispersion, the remaining soil sample test results showed non-dispersible while synthetic discrimination determined as dispersion or transition.

(3) The modified double-hydrometer test results are most consistent with synthetic discrimination results, only five groups of soil sample results showed inconsistent with the synthetic discrimination results, which indicate that the double-hydrometer test discrimination standard proposed by this paper is right.

(4) Comparing 17 groups soil samples of pore water soluble salts test results with the synthetic discrimination results, there are only 3 groups of soil samples are consistent , and another 6 groups of soil samples test results are determined as transition while synthetic discrimination determined as dispersion, the remaining soil sample test results are determined as non-dispersible while synthetic discrimination determined as dispersion or transition.
From the above tests results, for the crumb test, pinhole test, double-hydrometer test, pore water soluble salt test four kinds of dispersive clay discrimination methods, considering of the particularity of the soil in this region, the first three test methods are more efficient and reliable, they can be the main basis to discriminate the clay dispersion.

From the analysis of mineral composition of soil samples, due to illite is also a relatively unstable weathered intermediate product, in alkaline condition, it will adsorbs a large amount of $\mathrm{Na}+$ when it take off the potassium, so, it has highly dispersity as montmorillonite. Through testing the 26 groups reservoir dam soil samples, we can get that when the soil is free of montmorillonite, while illite soil content $6.5 \%-30.0 \%$, the clay also show dispersition.

\section{CONCLUSION}

(1) Many practical engineering and survey results have shown that the mineral content of clay is most illite in Zhejiang area, so, the main factor that causes soil dispersion is illite.

(2) By comparison with test results, the crumb test and the pinhole test results are more consistent with the synthetic discrimination results, these two test methods are more directly and effectively reflect the dispersion of soil, so, they can be the main basis to discriminate this clay dispersion.

(3) For the special case of the illite clay, this paper modified the double-hydrometer test discrimination standard and proposed the discrimination standard of doublehydrometer test is non-dispersion soil, dispersity $<60 \%$; transition soil, dispersity $60 \% \sim 80 \%$; dispersion soil, dispersity $>80 \%$. By analyzing and comparing hundreds of clay groups test results, obtaining that the modified doublehydrometer test discrimination standard can be used as the main basis to discriminate clay dispersion for Zhejiang illite clay.

(4) Due to different test methods have different mechanisms, which cannot be comprehensively discriminated soil dispersion by single one test, so, it is recommended to take the synthetic discrimination method to discriminate the clay dispersion accurately.

\section{ACKNOWLEDGMENT}

The paper is acknowledged to Fund Project: Zhejiang Science and Technology Program (2013F10035); Zhejiang Provincial Water Conservancy Science and Technology Project (RC1505); Operation and maintenance of water conservancy science and technology innovation service platform in Zhejiang Province (A201500017).

\section{REFERENCES}

[1] People's Republic of China Ministry of Water Resources. SL2512000, Water Resources and Hydropower Engineering Natural building materials and investigation procedures[S]. Beijing: China Water Conservancy and Hydropower Press, 2000.

[2] Jinqian Dang, Xiaoting Ma, Zhonglin Sun, etc. Experimental study on erosion dispersion of core material with cracks[J]. journal of hydraulic engineering, 2012, (09): 1103-1107

[3] Henghui Fan, Gaowen Zhao, Hongliang Li. The Status and Prospects of Dispersive clay[J]. rock and soil mechanics, 2010, 31(Supplement1): 108-114. 
[4] SHERARD J L, DUNNIGAN L P, DECKER R S. Some engineering problems with dispersive Cays[C]//Dispersive Clays, Related Piping, and Erosion in Geotechnical Projects, ASTM STP 623, J.L. Sherard, R.S.Decker, Eds., Chicago, USA: American Society for Testing and Material, 1977: 3-12.

[5] BELL F G, DE BRUYN IA. Sensitive, expansive,dispersive and collapsible soils[J]. Bulletin of the International Association of Engineering Geology,1997, 56: 19-38.

[6] The American Society for Testing and Material. D4221-99, Standard test method for dispersive characteristics of clay soil by double hydrometer[S]. West Conshohocken:ASTM, 1999.

[7] The American Society for Testing and Material. D4647-93, Standard test method for identification and classification of dispersive clay soils by the pinhole test[S]. West Conshohocken: ASTM, 1993.

[8] The American Society for Testing and Material. D6572-00, Standard test methods for determining dispersive characteristics of clayey soils by the crumb test[S]. West Conshohocken: ASTM, 2000.
[9] Qingyue Zhang. Experimental study on Xiaolangdi cohesive soil dispersing properties[J].Yellow River, 1981, (5): 8-12

[10] Henghui Fan, Peng Li, Juanli Ju. On the dispersive clay and Identification[J].Water Resources Construction \& Engineering, 2004, (2): $34-38,59$.

[11] Henghui Fan, Lingwei Kong, Hongliang Li, etc. Majiashu dam impervious earth material dispersion discrimination and modified test[J]. rock and soil mechanics, 2010, 31(1): 193-198

[12] Zhanliang Tian, Huili Zhang, Henghui Fan. Summary of clay dispersion method of identifying research and engineering contro measures[J]. Hydroelectric Engineering, 2010, 29(2): 204-209

[13] Min Cao, Bao Wang. Comparative study of test methods for identification of clay dispersion. China Rural Water and Hydropower, 2012, (03): 97-100.

TABLE I. Test Soil SAmples Basic Physical Property

\begin{tabular}{|c|c|c|c|c|c|c|c|c|}
\hline \multirow{2}{*}{$\begin{array}{l}\text { Numbering of } \\
\text { soil sample }\end{array}$} & \multirow{2}{*}{$\begin{array}{l}\text { specific } \\
\text { gravity }\end{array}$} & \multicolumn{3}{|c|}{ particle composition $(\%)$} & \multirow{2}{*}{$\begin{array}{l}\text { liquid limit } \\
\mathbf{w}_{L} / \%\end{array}$} & \multirow{2}{*}{$\begin{array}{c}\text { plastic limit } \\
\mathrm{w}_{\mathrm{P}} / \%\end{array}$} & \multirow{2}{*}{$\begin{array}{l}\text { plasticity } \\
\text { index } I_{P}\end{array}$} & \multirow{2}{*}{$\begin{array}{c}\text { Fine Soils } \\
\text { According to } \\
\text { Plasticity } \\
\text { Diagram } \\
\end{array}$} \\
\hline & & $\begin{array}{l}>0.075 \\
/ \mathrm{mm}\end{array}$ & $\begin{array}{c}0.075 \sim 0.005 \\
/ \mathrm{mm}\end{array}$ & $\begin{array}{c}<0.005 \\
/ \mathrm{mm}\end{array}$ & & & & \\
\hline D1 & 2.69 & 28.7 & 36.3 & 35.0 & 24.9 & 14.9 & 10.0 & CL \\
\hline D2 & 2.70 & 26.5 & 35.6 & 37.9 & 26.3 & 16.3 & 10.0 & CL \\
\hline D3 & 2.70 & 19.4 & 41.2 & 39.4 & 27.4 & 17.0 & 10.4 & CL \\
\hline D4 & 2.69 & 23.3 & 41.5 & 35.2 & 26.8 & 16.7 & 10.1 & $\mathrm{CL}$ \\
\hline D5 & 2.70 & 26.8 & 40.3 & 32.9 & 27.0 & 16.4 & 10.6 & CL \\
\hline D6 & 2.69 & 17.4 & 47.1 & 35.5 & 25.6 & 15.2 & 10.4 & $\mathrm{CL}$ \\
\hline D7 & 2.70 & 25.2 & 41.4 & 33.4 & 27.0 & 16.7 & 10.3 & CL \\
\hline D8 & 2.70 & 26.7 & 39.3 & 34.0 & 27.1 & 16.5 & 10.6 & CL \\
\hline D9 & 2.69 & 28.4 & 37.8 & 33.8 & 26.1 & 15.8 & 10.3 & CL \\
\hline S1 & 2.72 & 22.3 & 37.8 & 39.9 & 29.8 & 17.8 & 12.0 & CL \\
\hline S2 & 2.72 & 19.9 & 36.0 & 44.1 & 28.5 & 16.1 & 12.4 & CL \\
\hline S3 & 2.71 & 20.9 & 38.6 & 40.5 & 29.0 & 17.4 & 11.6 & CL \\
\hline S4 & 2.71 & 27.7 & 38.7 & 33.6 & 28.7 & 17.0 & 11.7 & $\mathrm{CL}$ \\
\hline S5 & 2.70 & 24.0 & 39.1 & 36.9 & 26.3 & 15.7 & 10.6 & CL \\
\hline S6 & 2.69 & 24.5 & 38.8 & 36.7 & 26.3 & 16.2 & 10.1 & CL \\
\hline S7 & 2.69 & 26.7 & 37.3 & 36.0 & 26.2 & 16.1 & 10.1 & CL \\
\hline S8 & 2.68 & 29.3 & 37.9 & 32.8 & 26.2 & 16.0 & 10.0 & CL \\
\hline $\mathrm{Z1}$ & 2.69 & 39.1 & 30.9 & 30.0 & 24.5 & 13.6 & 10.9 & CL \\
\hline $\mathrm{Z} 2$ & 2.69 & 18.0 & 52.0 & 30.0 & 27.3 & 16.6 & 10.7 & $\mathrm{CL}$ \\
\hline $\mathrm{Z3}$ & 2.70 & 17.9 & 50.5 & 31.6 & 34.5 & 20.8 & 13.7 & CL \\
\hline $\mathrm{Z4}$ & 2.70 & 16.8 & 48.1 & 35.1 & 22.6 & 12.5 & 10.1 & CL \\
\hline Z5 & 2.69 & 33.4 & 36.6 & 30.0 & 25.3 & 13.6 & 11.7 & $\mathrm{CL}$ \\
\hline Z6 & 2.73 & 2.5 & 57.1 & 40.4 & 24.9 & 14.7 & 10.2 & $\mathrm{CL}$ \\
\hline $\mathrm{Z7}$ & 2.71 & 4.8 & 56.5 & 38.7 & 30.0 & 17.9 & 12.1 & $\mathrm{CL}$ \\
\hline Z8 & 2.70 & 8.9 & 56.0 & 35.1 & 26.7 & 16.5 & 10.2 & $\mathrm{CL}$ \\
\hline Z9 & 2.74 & 3.0 & 38.6 & 58.4 & 37.2 & 20.5 & 16.7 & CL \\
\hline
\end{tabular}


TABLE II. ANALYSIS OF EXPERIMENTAL SOIL ClAY MiNERAL COMPOSITION

\begin{tabular}{|c|c|c|c|c|}
\hline Numbering of soil sample & illite/\% & montmorillonite/\% & kaolin/\% & Other minerals $/ \%$ \\
\hline D1 & 16.4 & 0 & 4.9 & 78.7 \\
\hline D2 & 16.0 & 0 & 0.0 & 84.0 \\
\hline D3 & 16.7 & 0 & 0.0 & 83.3 \\
\hline D4 & 14.8 & 0 & 0.0 & 85.2 \\
\hline D5 & 11.5 & 0 & 5.9 & 82.6 \\
\hline D6 & 10.6 & 0 & 3.9 & 85.5 \\
\hline D7 & 16.0 & 0 & 5.6 & 78.4 \\
\hline D8 & 13.7 & 0 & 3.4 & 82.9 \\
\hline D9 & 12.4 & 0 & 1.5 & 86.1 \\
\hline S1 & 10.8 & 0 & 9.0 & 80.2 \\
\hline S2 & 10.3 & 0 & 7.5 & 82.2 \\
\hline S3 & 19.9 & 0 & 6.9 & 73.2 \\
\hline S4 & 27.6 & 0 & 1.2 & 71.2 \\
\hline S5 & 17.0 & 0 & 7.4 & 75.6 \\
\hline S6 & 17.0 & 0 & 7.5 & 75.5 \\
\hline S7 & 13.2 & 0 & 8.4 & 78.4 \\
\hline S8 & 13.0 & 0 & 6.6 & 80.4 \\
\hline $\mathrm{Z} 1$ & 13.8 & 0 & 0.0 & 86.2 \\
\hline $\mathrm{Z} 2$ & 9.8 & 0 & 0.0 & 90.2 \\
\hline $\mathrm{Z3}$ & 6.6 & 0 & 3.2 & 90.2 \\
\hline $\mathrm{Z} 4$ & 8.7 & 0 & 0.0 & 91.3 \\
\hline $\mathrm{Z} 5$ & 11.0 & 0 & 7.5 & 81.5 \\
\hline Z6 & 6.5 & 0 & 0.0 & 93.5 \\
\hline $\mathrm{Z7}$ & 10.5 & 0 & 0.6 & 89.5 \\
\hline $\mathrm{Z} 8$ & 14.5 & 0 & 2.6 & 82.9 \\
\hline Z9 & 14.5 & 0 & 9.5 & 76.0 \\
\hline
\end{tabular}


TABLE III. SOIL DISPERSION DISCRIMINATION RESULTS

\begin{tabular}{|c|c|c|c|c|c|c|c|c|c|c|c|c|c|c|}
\hline \multirow{3}{*}{$\begin{array}{l}\text { Numbering } \\
\text { of soil } \\
\text { sample }\end{array}$} & \multirow{3}{*}{$\begin{array}{l}\text { double- } \\
\text { hydrometer } \\
\text { test }\end{array}$} & \multirow{2}{*}{\multicolumn{2}{|c|}{ crumb test }} & \multicolumn{4}{|c|}{ pore water soluble salts test } & \multicolumn{6}{|c|}{ pinhole test } & \multirow{3}{*}{$\begin{array}{l}\text { Soil sample } \\
\text { dispersion of } \\
\text { synthetic } \\
\text { discrimination }\end{array}$} \\
\hline & & & & & & & Discrimi- & & water & inded & Ended & water & Discrimi & \\
\hline & & level & $\begin{array}{l}\text { Discrimi- } \\
\text { nation }\end{array}$ & \multicolumn{2}{|c|}{$\begin{array}{c}\text { cation } \\
\text { content }(1 / n) \\
\text { mmol/L }\end{array}$} & $\%$ & & $\mathrm{~g} / \mathrm{cm}^{3}$ & $\mathrm{~mm}$ & $\mathrm{~mm}$ & $\mathrm{ml} / \mathrm{s}$ & - & & \\
\hline D1 & 79.3 & 4 & $\begin{array}{c}\text { highly } \\
\text { dispersed }\end{array}$ & 2.20 & 5.55 & 40 & transition & 1.81 & 180 & 2.0 & 1.56 & turbid & transition & dispersion \\
\hline D2 & 69.2 & 2 & transition & 2.30 & 8.25 & 28 & $\begin{array}{c}\text { non- } \\
\text { dispersible }\end{array}$ & 1.78 & 1020 & 1.0 & 2.94 & $\begin{array}{l}\text { slight } \\
\text { turbid }\end{array}$ & $\begin{array}{c}\text { non- } \\
\text { dispersible }\end{array}$ & $\begin{array}{c}\text { non- } \\
\text { dispersible }\end{array}$ \\
\hline D3 & 76.1 & 2 & transition & 1.70 & 5.70 & 30 & $\begin{array}{c}\text { non- } \\
\text { dispersible }\end{array}$ & 1.76 & 380 & 3.0 & 1.85 & turbid & transition & transition \\
\hline D4 & 93.5 & 4 & $\begin{array}{c}\text { highly } \\
\text { dispersed }\end{array}$ & 2.50 & 8.01 & 31 & $\begin{array}{c}\text { non- } \\
\text { dispersible }\end{array}$ & 1.74 & 380 & $<2.0$ & 1.02 & turbid & transition & dispersion \\
\hline D5 & 96.3 & 4 & $\begin{array}{c}\text { highly } \\
\text { dispersed }\end{array}$ & 2.00 & 6.81 & 29 & $\begin{array}{c}\text { non- } \\
\text { dispersible }\end{array}$ & 1.72 & 380 & $<3.0$ & 1.25 & turbid & transition & dispersion \\
\hline D6 & 85.1 & $3 \sim 4$ & disperse & 2.00 & 7.82 & 26 & $\begin{array}{c}\text { non- } \\
\text { dispersible }\end{array}$ & 1.73 & 180 & I & 1.58 & $\begin{array}{l}\text { slight } \\
\text { turbid }\end{array}$ & transition & dispersion \\
\hline D7 & 94.3 & 4 & $\begin{array}{c}\text { highly } \\
\text { dispersed }\end{array}$ & 2.90 & 7.50 & 39 & $\begin{array}{c}\text { near } \\
\text { transition }\end{array}$ & 1.73 & 50 & 2.0 & 1.05 & $\begin{array}{c}\text { moderate } \\
\text { turbid }\end{array}$ & dispersion & dispersion \\
\hline D8 & 98.5 & 4 & $\begin{array}{c}\text { highly } \\
\text { dispersed }\end{array}$ & 4.40 & 9.49 & 46 & transition & 1.71 & 180 & 2.0 & 1.79 & turbid & transition & dispersion \\
\hline D9 & 94.1 & 4 & $\begin{array}{c}\text { highly } \\
\text { dispersed }\end{array}$ & 2.50 & 5.87 & 43 & transition & 1.68 & 1020 & 2.5 & 3.57 & $\begin{array}{l}\text { slight } \\
\text { turbid }\end{array}$ & \begin{tabular}{|c|} 
non- \\
dispersible
\end{tabular} & dispersion \\
\hline S1 & 78.9 & 3 & dispersion & 2.00 & 4.40 & 45 & transition & 1.74 & 1020 & 3.0 & 2.63 & $\begin{array}{l}\text { slight } \\
\text { turbid }\end{array}$ & $\begin{array}{c}\text { non- } \\
\text { dispersible }\end{array}$ & transition \\
\hline S2 & 88.1 & 4 & $\begin{array}{c}\text { highly } \\
\text { dispersed }\end{array}$ & 4.10 & 9.02 & 45 & transition & 1.72 & 380 & $>1.5$ & 1.52 & $\begin{array}{c}\text { moderate } \\
\text { turbid }\end{array}$ & transition & dispersion \\
\hline S3 & 85.1 & 4 & $\begin{array}{c}\text { highly } \\
\text { dispersed }\end{array}$ & 2.48 & 5.92 & 42 & transition & 1.71 & 1020 & 1.0 & 2.27 & transparent & $\begin{array}{c}\text { non- } \\
\text { dispersible }\end{array}$ & dispersion \\
\hline S4 & 98.8 & 4 & $\begin{array}{c}\text { highly } \\
\text { dispersed }\end{array}$ & 1.90 & 4.81 & 40 & transition & 1.76 & 50 & 3.0 & 0.37 & turbid & dispersion & dispersion \\
\hline S5 & 95.7 & 4 & $\begin{array}{c}\text { highly } \\
\text { dispersed }\end{array}$ & 1.90 & 5.20 & 37 & $\begin{array}{c}\text { non- } \\
\text { dispersible }\end{array}$ & 1.73 & 50 & 4.0 & 1.67 & turbid & dispersion & dispersion \\
\hline S6 & 80.9 & $3 \sim 4$ & dispersion & 2.30 & 7.14 & 32 & $\begin{array}{c}\text { non- } \\
\text { dispersible }\end{array}$ & 1.74 & 380 & 4.0 & 1.00 & turbid & transition & dispersion \\
\hline S7 & 88.1 & 4 & $\begin{array}{c}\text { highly } \\
\text { dispersed }\end{array}$ & 2.10 & 5.20 & 40 & transition & 1.74 & 1020 & 3.0 & 3.11 & turbid & $\begin{array}{c}\text { non- } \\
\text { dispersible }\end{array}$ & dispersion \\
\hline S8 & 90.2 & 4 & $\begin{array}{c}\text { highly } \\
\text { dispersed }\end{array}$ & 2.60 & 7.64 & 34 & $\begin{array}{c}\text { non- } \\
\text { dispersible }\end{array}$ & 1.73 & 1020 & 1.0 & 2.17 & $\begin{array}{l}\text { slight } \\
\text { turbid }\end{array}$ & $\begin{array}{c}\text { non- } \\
\text { dispersible }\end{array}$ & dispersion \\
\hline $\mathrm{Z} 1$ & 89.0 & 2 & transition & I & I & I & I & 1.68 & 180 & 1.6 & 1.56 & $\begin{array}{l}\text { slight } \\
\text { turbid }\end{array}$ & transition & transition \\
\hline $\mathrm{Z} 2$ & 58.9 & 1 & $\begin{array}{c}\text { non- } \\
\text { dispersible }\end{array}$ & I & I & I & I & 1.61 & 1020 & 1.0 & 3.12 & clear & $\begin{array}{c}\text { non- } \\
\text { dispersible }\end{array}$ & $\begin{array}{c}\text { non- } \\
\text { dispersible }\end{array}$ \\
\hline $\mathrm{Z} 3$ & 68.7 & 1 & $\begin{array}{c}\text { non- } \\
\text { dispersible }\end{array}$ & I & I & I & I & 1.57 & 380 & 2.5 & 6.90 & $\begin{array}{c}\text { gradual } \\
\text { turbid }\end{array}$ & transition & transition \\
\hline $\mathrm{Z4}$ & 90.6 & 3 & dispersion & I & I & I & I & 1.64 & 50 & 3.0 & 1.33 & $\begin{array}{c}\text { moderate } \\
\text { turbid }\end{array}$ & dispersion & dispersion \\
\hline $\mathrm{Z} 5$ & 79.8 & 2 & transition & I & I & I & I & 1.72 & 380 & 2.1 & 2.04 & $\begin{array}{l}\text { slight } \\
\text { turbid }\end{array}$ & transition & transition \\
\hline Z6 & 96.8 & 4 & \begin{tabular}{|c|} 
highly \\
dispersed
\end{tabular} & I & I & I & I & 1.63 & 50 & 2.2 & 1.15 & turbid & dispersion & dispersion \\
\hline $\mathrm{Z7}$ & 42.9 & 1 & $\begin{array}{c}\text { non- } \\
\text { dispersible }\end{array}$ & I & I & I & I & 1.58 & 1020 & 1.1 & 1.56 & clear & $\begin{array}{c}\text { non- } \\
\text { dispersible }\end{array}$ & $\begin{array}{c}\text { non- } \\
\text { dispersible }\end{array}$ \\
\hline $\mathrm{Z} 8$ & 81.5 & 1 & $\begin{array}{c}\text { non- } \\
\text { dispersible }\end{array}$ & I & I & I & I & 1.69 & 380 & 1.6 & 1.58 & $\begin{array}{c}\text { moderate } \\
\text { turbid }\end{array}$ & transition & transition \\
\hline Z9 & 69.9 & 1 & $\begin{array}{c}\text { non- } \\
\text { dispersible }\end{array}$ & I & I & I & I & 1.48 & 1020 & 1.8 & 1.53 & clear & $\begin{array}{c}\text { non- } \\
\text { dispersible }\end{array}$ & $\begin{array}{c}\text { non- } \\
\text { dispersible }\end{array}$ \\
\hline
\end{tabular}

